日臨外会誌 $66(9), 2156-2159,2005$

症例

十二指腸潰瘍術後の吻合部潰瘍による胃空腸結腸㾞の 1 例

天神会新古賀病院外科

飯田洋也高尾貴史島袋誠守草野敏臣

症例は62歳, 男性, 数力月前から続く下痢と体重減少で近医受診し, 当院紹介となる. 48歳時, 穿孔性十二指腸潰瘍に対し幽門側胃切除術, Billroth II 法再建の既往あり. 来院 時, 極度のるい瘦を認め, 低栄養状態であった。血液検査成績では, ヘマトクリット 31.0 $\%$, 血色素 $10.4 \mathrm{~g} / \mathrm{dl}$ と軽度の筫血を呈し, 血清総蛋白 $4.1 \mathrm{~g} / \mathrm{dl}$, 血清アルブン $2.2 \mathrm{~g} / \mathrm{dl}$ と低蛋白, 低アルプミン血症を認めた. 畽場マーカーは CEA7.8ng $/ \mathrm{ml}, \mathrm{CA} 19-948 \mathrm{U} / \mathrm{ml}$ と軽度上昇を認めた。悪性腫場を疑い，下部消化管内視鏡検査を施行したところ，横行 結腸に狭窄部を認め，その口側が双口となり，小腸と瘦孔を形成していた。そこで上部 消化管内視鏡検查を施行したところ, 胃空腸吻合部に多発潰瘍を認め, 一部横行結腸に 穿通していた．胃空腸吻合部潰瘍の横行結腸穿通と診断し，残胃全摘，瘦孔を含む結腸 右半切除術を施行した，胃切除後の吻合部潰瘍は比較的多く認められるが, 横行結腸に 穿通するのは稀である。ささらに主訴が便通異常で診断に苦慮したため, 興味深い症例と 考え報告する.

卖引用語：胃空腸結腸疸，吻合部實瘍

\section{緒 言}

胃切除後の胃空腸結腸瘦は, 吻合部潰瘍の重篤な合 併症の一つである. 今回, 便通異常を主訴に来院され,

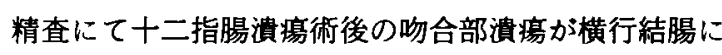
穿通していた稀な症例を経験したので, 若干の文献的 考察を加えて報告する.

$$
\text { 症例 }
$$

患者：62歳, 男性.

主訴: 下痢, 体重減少。

既往歴：48歳時, 穿孔性十二指腸謴場に対し, 幽門 側胃切除術, Billroth II 法再建.

家族歴：特記すべきことなし.

現病歴: 平成 16 年 2 月頃より, 頻回の下痢が出現し, 約 5 力月て $15 \mathrm{~kg}$ の体重隇少を認めた。近医にて内服薬 を処方されるも改善なく, 精查加療目的に平成 16 年 7 月17日, 当院入院となった。

入院時現症: 身長 $167.1 \mathrm{~cm}$, 体重 $45.1 \mathrm{~kg}$, るい瘦著 明で,両下肢に浮腫を認めた. 腹部所見では圧痛なく,

2005 年 4 月11日受付 2005 年 6 月 9 日採用

〈所属施設住所〉

T 830-8577 久留米市天神町 120

\section{腄瘤は触知しなかった。}

入院時検查成績 : 赤血球 $3.08 \times 10^{6} / \mu 1$, 血色素 10.7 $\mathrm{g} / \mathrm{dl}$, ヘマトクリット $31.7 \%$ と軽度の貧血を呈し, 血清 総蛋白 $4.1 \mathrm{~g} / \mathrm{dl}$, 血清アルプミン $2.2 \mathrm{~g} / \mathrm{dl}$ と低蛋白, 低 アルプン血症を認めた. CEA 7.8ng/ml, CA19-9 48 $\mathrm{U} / \mathrm{ml}$ と腫劰マーカーは軽度上昇していた. 血中ガス トリン値は正常であり，空腹時血糖も正常であった。

下部消化管造影検查所見 : 横行結腸の脾韽曲部より に狭窄所見を認め，一部小腸が造影されたため，小腸 との瘦孔の存在が示唆された（図 1 )。

下部消化管内視鏡検查所見：狭窄部は浮腫状に隆起 しており，その口側は小腸粘膜が確認できた。それ以 上は患者の疼痛, 前処置不良のため, 観察できなかっ た. 狭窄部の生検結果は Group I であった。

上部消化管造影検査所見：胃空腸吻合部から横行結 腸の脾彎曲部付近に造影剤が流出し, 胃空腸結腸瘻が 存在していた (図 2 ).

上部消化管内視鏡検查所見：吻合部に白苔の付着し た潰場が多発し，輸入脚，輸出脚がそれぞれ確認でき た.また，吻合部の小腸側に横行結腸との瘦孔部が確 認できた (図 3 ).

以上より，十二指腸潰韵術後の吻合部潰瘍による胃 


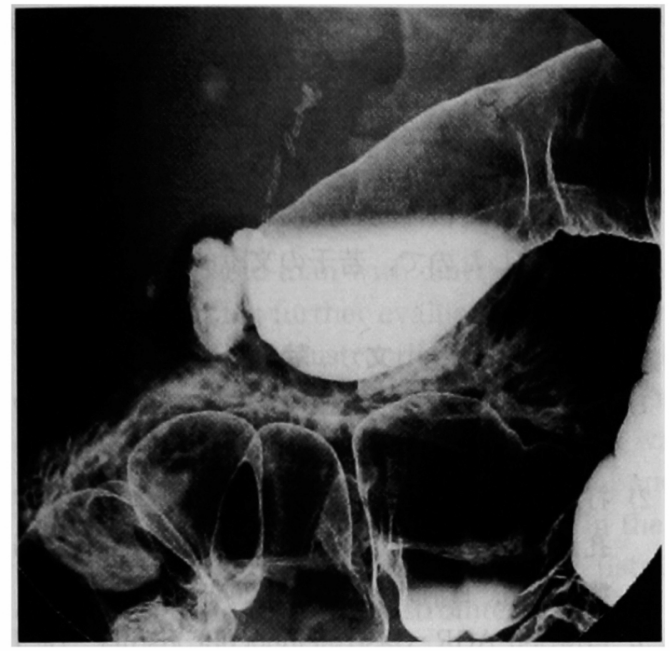

図 1 下部消化管造影検査所見 : 横行結腸の脾臂曲 部よりに狭窄所見を認め,一部小腸が造影された。

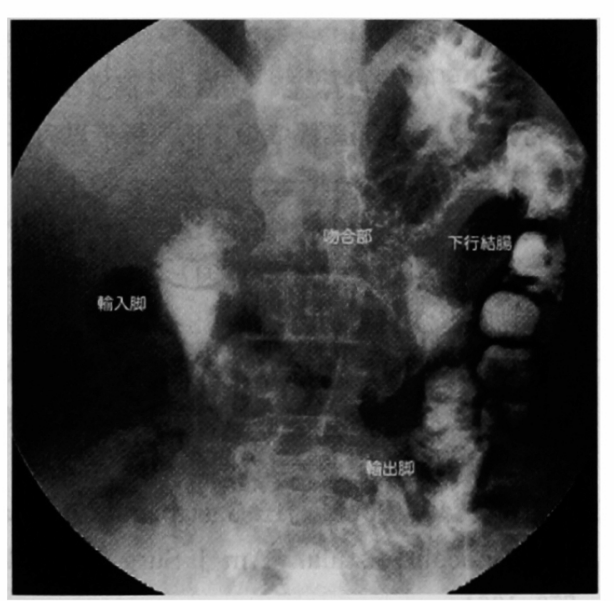

図 2 上部消化管造影検査所見：胃空腸吻合部 から下行結腸に造影剤が流出し, 胃空腸結腸瘒 が存在することが確認できた。

空腸結腸瘒と診断し，手術を施行した。

手術所見：前回の手術創に沿って正中切開で開腹, 前回手術は, 幽門側胃切除術が施行されており, Treitz 勒帯より約 $20 \mathrm{~cm}$ の空腸を結腸後で挙上し, Billroth II 法で再建されていた。術式は, 残胃全摘, 瘦孔部を含 む結腸右半切除，小腸部分切除を施行した。再建は, Roux-en-Y 法で行うこととし，末梢側の空腸を結腸 後で挙上, Treitz 勒帯から約 $10 \mathrm{~cm}$ の空腸と食道空腸 吻合部から約 $40 \mathrm{~cm}$ の空腸を吻合した。回腸横行結腸 吻合は端々吻合で行った。

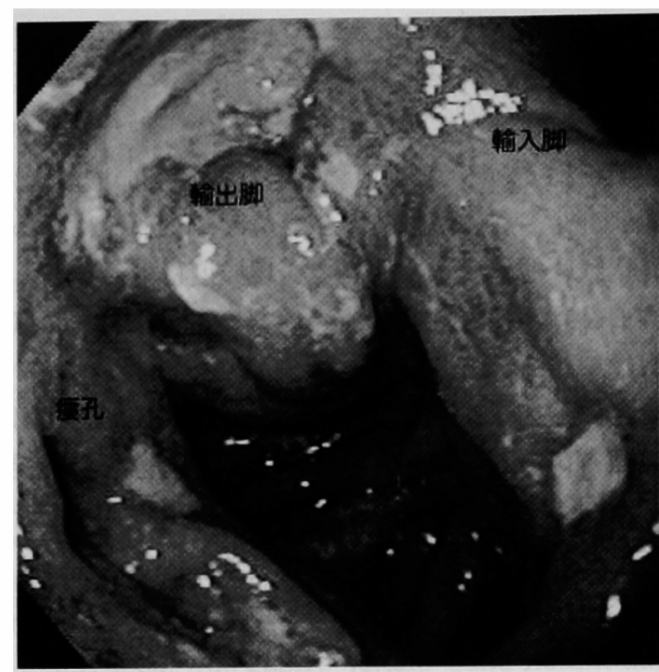

図 3 上部消化管内視鏡検査所見：吻合部に白苔の 付着した潰瘍が多発し, 輸入脚, 輸出脚, 瘦孔部が それぞれ確認できた。

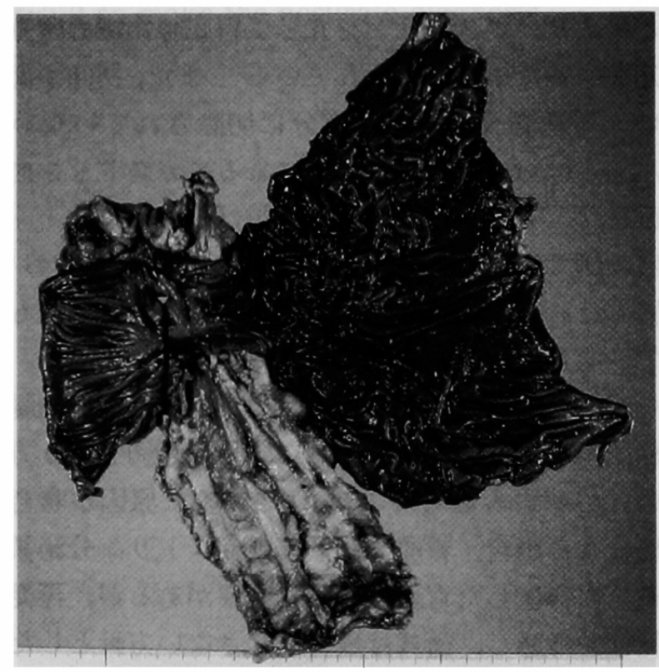

図 4 切除標本肉眼所見：吻合部の空腸側と横行結 腸への癗孔が確認でき, 病理組織学的に悪性所見 は認めなかった。

切除標本肉眼所見：吻合部潰瘍が結腸に穿通し，吻 合部の空腸側と横行結腸に㾇孔を形成していた。病理 組織学的に悪性所見は認めなかった（図 4 ).

術後経過は良好で, 下痢症状, 下腿浮腫は改善し, 術後 3 週間目に軽快退院した.

$$
\text { 考察 }
$$

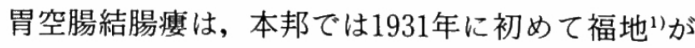


報告して以来，検索しえた限り自験例を含めて78例の 報告例がある 2 2 ? .

本症の症状としては，下痢，るい瘦，䔬臭曖気が 3 主徴とされているが8)，自験例を含む78例の検討では， 下痢は $71 \%$ ，るい瘦は $61 \%$ ，黄臭暧気は $34 \%$ に認め， 鿓臭㖟気は他の症状と比へて発現頻度は低かった，自 験例でも頻回の下痢, るい瘦は認めたが, 莫臭曖気の 症状はなかった。

瘦孔の存在は,下部消化管内視鏡では $100 \%$ 診断可能 との報告があるが2(4) 6), 自験例では下部消化管内視鏡 では確定診断に至らず，やはり，上部消化管検査を組 み合わせて診断する必要があると考えられた。

本症の原疾患としては，十二指腸謴瘍術後が46例と 最も多く，次いで胃潰瘍術後が14例であり，そのうち 調べ得た限りでは40例が Billroth II 法再建であっ た2)ー7. その理由として，十二指腸に続く幽門腺領域が 残存してしまうと, Billroth II 法による再建が幽門腺 領域への酸の流入を停止させ, feed backが絶たれる ことにより，ガストリンを介して胃底腺領域の酸分泌 を六進するためと考えられている7.また，初回手術に おいて胃底腺分布領域が充分に切除されていない症 例, Zollinger-Ellison 症候群による高ガストリン血症 の存在なども本症の成因として挙げられる ${ }^{577) 99}$.

自験例では，通常の幽門側胃切除が施行されており， 残胃もそれほど大きくはなく，血中ガストリン值も正 常で，明らかな原因は不明であった。

一般に, 治療は㿉孔を含めた胃, 空腸, 横行結腸の 切除, 再建が行われる. さらに, 全幹迷切を行う方が よいとの報告もある゙!. 自験例のように原因が吻合部 漬癔による場合，胃酸分泌領域，ガストリン分泌領域 を充分に考虑した胃切除を行う必要があるが，再発の 可能性を考虑し，術式は残胃を残さない方針とした，

本症では, 不消化物が瘜孔を通して直接大腸に通過 すること，また，粪便が胃や小腸に逆流して腸内細菌 丵の異常をきたすことにより，吸収不良をおこして低 栄養になりやすい ${ }^{255) 6)}$. 低栄養を主因とする死亡例の
報告もあるため ${ }^{(0)}$ ，十二指腸潰瘍術後て，頻回の下痢， 低栄養，るい瘦を認める患者には，本症を念頭に置き， 早期の診断, 治療が必要と考えられた。

\section{結 語}

十二指腸潰瘍術後の吻合部潰瘍による胃空腸結腸瘦 の 1 例を経験したので, 若干の文献的考察を加えて報 告した.

\section{文 献}

1）福地省吾：後胃腸吻合後に発生せる胃結腸罴瘦の 1 例に就いて.実地医家と臨 $8: 363-365,1931$

2）打出啓二, 柏崎正樹, 問狩洋一他: 十二指謴瘍穿 孔に対する胃切除 B-II再建後の胃空腸横行結腸 瘦の 1 例. 日消外会誌 $32: 2659-2663 ， 1999$

3) Lowdon AGR : Gastrojejunocolic fistula. $\mathrm{Br} J$ Surg $41: 113-128,1953$

4）沼 謙司, 山口 剛, 石橋治昭：吻合部潰疸によ る胃空腸横行結腸瘦の 1 例. 滋賀医 $23: 52-54$, 2001

5) 河野通一, 小林伸行, 谷 明博他: 高度な脂肪肝 を合併した胃空腸結腸瘦の 1 例。新千里病医誌 $9: 50-55,1998$

6）吉窒誠司, 小畑伸一郎, 本多 恵地：内視鏡で確 認できた吻合部潰瘍穿孔が原因と思われる胃空腸 横行結腸瘦のI例。消内視鏡 $8: 127-131,1996$

7) 玉井 修, 古川正人，中田俊則他：十二指腸潰場 術後生じた吻合部清疸による胃空腸横行結腸瘦の 2 例. 医療 $49: 149-152,1995$

8) Amricke JA, Ponka JL: Gastrocolic and gastrojejunocolic fistula. Am J Surg $107: 744-$ 750,1964

9）中山康夫，襄川公章，香川修司他：消化性潰瘍手 術後の潰瘍再発例について，日臨外会誌 $45 ：$ $1282-1290,1984$

10) Marshall SF : Gastrojejunocolic fistula. Ann Surg 145:770-782, 1957 


\title{
A CASE OF GASTRO-JEJUNO-COLIC FISTULA DUE TO PENETRATION OF STOMAL ULCER
}

\author{
Hiroya IIDA, Takashi TAKAO, Masamori SHIMABUKU and Toshiomi KUSANO \\ Department of Surgery, Tenjinnkai Shin-Koga Hospital
}

A 62-year-old man with diarrhea and a loss of weight over a period of several months was referred to the hospital for further evaluation. There were previous histories of undergoing a distal gastrectomy with Billroth II reconstruction for perforation of a duodenal ulcer at the age of 48 . The physical examination showed extreme emaciation and mild anemia. The serum level of total protein was $4.1 \mathrm{~g} /$ $\mathrm{dl}$, the albumin was $2.2 \mathrm{~g} / \mathrm{dl}$, the hematocrit was $31.0 \%$, and the hemoglobin was $10.4 \mathrm{~g} / \mathrm{dl}$. The serum levels of CEA and Ca19-9 rose to $7.8 \mathrm{ng} / \mathrm{ml}$ and $48 \mathrm{U} / \mathrm{ml}$, respectively. A colonoscopic examination and a barium enema study revealed stenosis in the transverse colon with double orifices on the oral side of the stenotic lesion which had formed a fistula in the small intestine. On the other side, diagnostic examination of the upper gastrointestinal tract revealed multiple peptic ulcers in the gastro-jejunostomic region penetrating the transverse colon. The preoperative diagnosis was gastro-jejuno-colic fistula due to penetration of a stomal ulcer. We performed a right hemicolectomy including the resection of the remnant stomach and fistula because we could not rule out a possibility of malignant lesion in the colon.

Stomal ulcer after gastrectomy is sometimes observed, however, the penetration of such a stomal ulcer to the transverse colon is extremely rare. We herein report an interesting case of the disease presented with defecation disturbance for that it was difficult to make the accurate diagnosis. 